\title{
Opportunistic Humanitarianism and Securitization Discomfort Along the Balkan Corridor: The Croatian Experience
}

Župarić-Iljić, Drago; Valenta, Marko

Source / Izvornik: Refugee Protection and Civil Society in Europe, 2019, 129 - 160

Book chapter / Poglavlje u knjizi

Publication status / Verzija rada: Accepted version / Završna verzija rukopisa prihvaćena za objavljivanje (postprint)

https://doi.org/10.1007/978-3-319-92741-1 5

Permanent link / Trajna poveznica: https://urn.nsk.hr/urn:nbn:hr:131:969375

Rights / Prava: In copyright/Zaštićeno autorskim pravom.

Download date / Datum preuzimanja: 2023-04-26

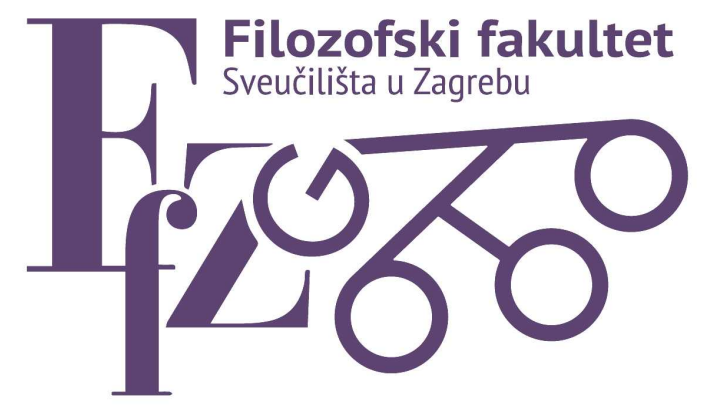

Repository / Repozitorij:

ODRAZ - open repository of the University of Zagreb

Faculty of Humanities and Social Sciences
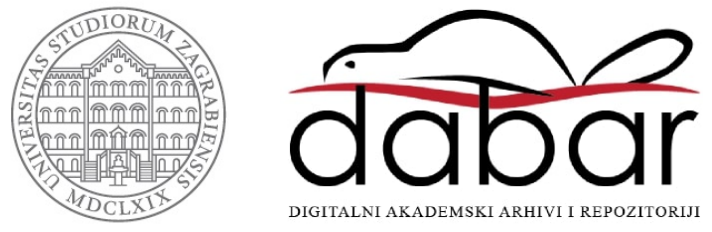


\author{
Drago ŽUPARIĆ-ILJIĆ \\ Institute for Migration and Ethnic Studies, Croatia \\ drago.zuparic@imin.hr \\ Marko VALENTA \\ Norwegian University of Science and Technology, Norway \\ marko.valenta@ntnu.no
}

\title{
Opportunistic Humanitarianism and Securitization Discomfort along the Balkan Corridor: the Croatian Experience
}

\begin{abstract}
Within the Balkan corridor Croatia combined state-driven 'crisis management measures', including organized, excessively controlled, swift transit of people, together with humanitarian practices of immediate care and assistance provided by state, civil society, religious and humanitarian organizations, and new solidarity initiatives. Basing our analysis on desk-study and expert semi-structured interviews, done in 2015/2016, we focus on complementing and competing dominant state-official and 'counter-hegemonic' civic and humanitarian organisations discourses and practices within the transit reception camps and on borders. While at the beginning majority of stakeholders were acting in humane/humanitarian and overtly supportive manner ('humanitarian opportunism'), later on, with gradual closure of the corridor, radicalization and securitization of state discourses, rhetoric and politics took place, leading to 'securitization discomfort' among pro-refugee actors. Consequently, humanitarian organisations and initiatives came into ambiguous position of balancing in-between their mission/orientation to help and to foster solidarity, and innate motivation to challenge and circumvent securitizing politics.
\end{abstract}

Key words: Croatia, refugees, crisis management, humanitarian opportunism, securitization discomfort, solidarity

\section{INTRODUCTION}

Both globally and at the level of the European Union (EU), we are witnessing the gradual deterioration of human and refugee rights, combined with the criminalization and militarization of many issues relating to the mobility of people and the ways in which states respond to the presence of a displaced population who cross borders. ${ }^{1}$ The EU did not find a common and effective solution for the recent mass-movement of more than a million people through the Balkan corridor, which was disputably referred to as the so-called refugee crisis. ${ }^{2}$ Some member states opted for restrictive military solutions, erecting walls and razor-blade wire fences, so as to stop the arrival of refugees on their borders. The Balkan countries decided to permit controlled passage for the massive transit of people. When the corridor ceased to exist, well-known restrictive policies of interception, detainment and forced return resulted in hazardous journeys, with detrimental consequences for people stuck somewhere along the Balkan route. ${ }^{3}$ The corridor episode has shown that member states had rather different 
understandings of what 'solidarity' means and developed many ways of circumventing it, by exercising distinct standards on accepting refugees and allowing access to protection.

The response of the Republic of Croatia was characterized by a combination of direct state-driven security policies including control, surveillance and detainment measures at borders, within reception centres, and in organized transit. During the corridor phase those strategies were enforced together with direct humanitarian assistance by the state, civil society organizations, activists, volunteers and other stakeholders, such as international, humanitarian, charity and faith-based organizations. Only a few refugees decided to stay and seek protection which had reasserted official Government's rhetoric in which Croatia is merely a transit territory on their journeys towards the West (Coleridge 2013; Valenta et al., 2015). Arguable, historical legacies and national trajectories - namely experiences in dealing with displaced populations (during the 1990s), as well as the recent national (pre-)electoral political context shaped the discourses and policies of managing refugees' transit through the corridor.

In this paper we explore the distinctive roles of actors actively engaged in providing support to refugees during their transit through Croatia, and stakeholders' roles in protecting refugees' rights and providing assistance for refugees' present-day integration. We focus mainly on competing and/or complementing discourses and practices between dominant stateofficial policies regarding the restricting of refugees' rights, and the humanitarian organisations' counter-hegemonic activities regarding the improvement of those rights and of fostering solidarity. In 2015 the state, civil society and humanitarian actors, as well as the media and the public, assumed somewhat similar positions regarding the organized transit of people through Croatian territory further west (Šelo Šabić and Borić, 2016). Todays' challenges following the closing of the corridor relate to opposing stances being taken as regards basic provisions for accessing the territory and status recognition procedure.

This chapter consists of several interrelated parts. First, we draw on certain theoretical premises from relevant studies of securitization, humanitarianism and solidarity within the forced migration frame. Secondly, we briefly present an event-analysis of the Balkan corridor so as to offer an overview to contextualise our further analysis. Main discussion is based on an explorative and analytical approach, which includes a desk study of state policies, regulations and of previous studies (including media and NGO reports), together with a thematic content analysis of transcripts (cf. Bryman, 2012, p.578-581), from a series of fifteen expert semistructured interviews. These included different national and regional non-state actors involved in providing aid and assistance to refugees along the corridor. Additionally, we use insights gained through participant observation in the field, at borders with Serbia and Slovenia, and within the reception areas (in transit centres/camps) in Croatia, which we frequently visited between September 2015 and March 2016. ${ }^{4}$

We posit that the first phase of dealing with the mass-movement of refugees through the Croatian part of the Balkan corridor was characterized by a 'crisis management' approach, one which has revealed the unique position of what we call 'opportunistic humanitarianism'. In this regard, the state and other actors handled the situation of refugees' and migrants' arrival in a transparently humanitarian way. The government seemed to oppose the militarization politics of neighbouring states, and diverted the anti-immigrant rhetoric of parliamentary rightist opposition within the country. However, later on, with post-electoral changes in the national political context - together with the tightening of the corridor - Croatian authorities increased their focus on further securitization. State discourses, rhetoric, politics and measures became more restrictive, which led to a 'securitization discomfort' among non-state actors. Consequently, after the corridor's closure, some of the engaged civil actors continued to work on protecting refugees' rights, with only a few opposing securitization measures which attempt to suppress solidarity with refugees. 


\section{UNDERSTANDING THE SECURITIZATION-HUMANITARIANISM-SOLIDARITY NEXUS}

In the Euro-Mediterranean area arrival of refugees has mostly been articulated as a humanitarian and as a security challenge, in which the securitization of European borders appears to be more important than facilitating access to territory and to forms of protection for people in need. Scholars have explained that the reshaping of current EU policies points to even more restrictive and exclusionary mechanisms of securitization and crisis management exceptionalism (Aydin, 2016; Alexandridis and Dalkıran, 2017). Alongside this, more thoughtful practices of solidarity, responsibility sharing and protection warranties in dealing with refugees have been called for and ostensibly employed. However, an intricate connection between security and migration regimes has been unmasked along the corridor, both in the camps and once again within humanitarian regimes.

The Copenhagen School set the agenda of securitization studies and for the investigation of the migration-security nexus. This approach has been particularly fruitful for the analysis of discursive practices through which migration as such is socio-politically framed as a security threat - one which longs for restrictive migration policies and securitizing solutions (Buzan, et al., 1998; Huysmans, 2006). Securitizing practices are usually introduced and utilized through various exclusionary measures which include, among others, border surveillance and control, secured or restricted mobility out or within the camps, a crisis and disaster management approach to mass-movements, as well as the more profound spectacularization of borders and mobility, together with the externalization of asylum and border regimes (Squire, 2009; De Genova, 2013).

The very idea that migrants and refugees create 'a crisis', represents the legitimization of repressive emergency practices which include various forms of control and oftentimes even physical as well as structural (institutional) violence. All of this would not be possible without the depoliticizing and dehumanizing frames for representations of refugees, who are being portrayed and perceived as 'a disorder' and threating subjects to the nation-state and proclaimed 'national order of things', or helpless and muted mass (Malkki, 1995; cf. Rajaram, 2002; Nyers, 2006). However, there have been inextricable dialectics between security and humanitarian regimes noted in every country along the Balkan corridor, albeit to varying degrees. Hungarian, Macedonian and Slovenian policies have been designated as more security oriented in comparison to Serbia and Croatia, whose policies were arguably more humanitarian, at least in the initial phase of the corridor's existence (cf. Beznec et al. 2016; Hameršak and Pleše, 2017b; Kogovšek Šalamon, 2016). ${ }^{5}$

Here, as posited by Harrell-Bond $(1999,2002)$ we understand 'humanitarian regime' as the hierarchically organized and bureaucratized policies and practices of the UN, the state(s), and inter-governmental and non-governmental humanitarian (aid, relief, charity) actors, who administer and provide the distribution of assistance for endangered population. The humanitarianism as the ideology relies on providing relief and reducing suffering of people who are affected by any kind of natural or man-made disaster. Traditionally, humanitarianism tends to separate from the political realm, and support the principles of humanity, presenting itself as impartial, neutral and independent. This is seldom the case. Humanitarian practices have negative consequences in silencing refugees whose identities are geographically and historically decontextualized, reduced to only legal terms of state-centric normativity, and stripped of their individuality and agency, as Malkki (1996, p.378-9) pointed out. On top of that, humanitarianism disregards refugees' perspectives and prospects, their agencies and identities, omitting to address their various experiences along the displacement cycle as a resource and potential for coping with distress, fostering resilience, and cherishing solidarity. 
In elaborating the humanitarian-security nexus, Watson writes how humanitarianism and securitization are contested concepts which both reflect terms and policies serving to legitimize emergency measures. In this sense humanitarianism is understood "as a sector of securitization, like state and societal securitization, meaning that it is a structured field of [humanitarian] practice that draws on existing discourses and institutions to enable the implementation of emergency measures" (Watson, 2011, p.3). Hence, there cannot be 'a specific turn' from securitization discourses and policies to humanitarian ones, because both are actually parts of the same dynamic continuum, relying on exceptional measures for governing displaced population. These complex and ambiguous, yet interrelated mechanisms of control, governance and aid Michel Agier calls 'Humanitarian Government', asserting the structural connectedness "between the humanitarian world (the hand that cares) and the police and military ordering (the hand that strikes)" (Agier, 2011, p.5). ${ }^{6}$ This is especially visible in the management of refugee camps where practices of humanitarian and of the security regime are mutually instrumentalized and fostered, unfolding in the emergency-relief activities of different actors. We posit that humanitarianism and securitization intertwine in dyadic relation, more often being complementary than opposed, while the forms of new humanitarianism include actors who tend to build more solidarity-prone humanitarian work (cf. Barnett and Weiss, 2008; Pries; Cantat and Feischmidt, in this volume).

The principle of solidarity, besides the known Durkhemian dichotomy, has been relatively under-researched in critical migration studies. It seems that solidarity is most often discussed in legal and political terms, as an inter-state and intergovernmental supranational tool of fair 'burden-sharing' between political subjects governed by the national security principles (cf. Goldner Lang, 2013). However, one study points that two thirds of Europeans are prone to express solidarity, not only to refugees, but to migrants in general (Bello, 2017, p.14). Other studies have dealt with the engagement of European civil society, or with the efforts of citizens to express a 'welcoming culture', consisting of compassion, hospitality and solidarity towards refugees, either as volunteers, charity-workers or just as ordinary people (Funk, 2016; Cantat, 2016; Feischmidt and Zakariás; Karakayali, in this volume). Addressing the singular and structural needs of refugees in Brussels, Dunkirk and Calais, Vandevoordt and Verschraegen (in this volume) conceptualize civil acts of solidarity which acquires a political character, as 'subversive humanitarianism'. Cantat and Feischmidt (in this volume) speak of forms of 'vernacular humanitarianism' by various state and civil actors operating within contexts of reception countries or during a phase of transit and of repressive immobilisation.

More critical understanding of solidarity as a part of humanitarianism logic, was proposed by Fassin (2012, p.3): he emphasizes asymmetrical relationships of aid-providers and aid-receivers, equalizing 'the politics of solidarity' as 'the politics of compassion' as 'the politics of inequality', which are in that sense "constitutive element of all humanitarian government". We agree that such forms of compassion and solidarity are affected and shaped by politics and power relations, yet we understand solidarity in a more positive way as less technocratic and instrumental and more philanthropic and altruistic mobilization that have potential to transcend securitization aspects of humanitarianism. Thus, solidarity with refugees might dissolve, or at least lessen, unequal relations epitomized in conceptualization of 'aidproviders' vs 'aid-receivers', beyond depoliticized and securitized space of immediate relief.

Different forms and strategies of humanitarianism have mostly been researched, explained and criticized in the context of conflicts and protracted forms of displacement, often within long-term settled camps (cf. Belloni, 2007; Harrell-Bond, 1999, 2002). However, lesser is known about the specific forms and logics of humanitarianism and solidarity taking place on borders and within short-term transit reception places, such as those along the Balkan corridor and within the transit reception camps. We will address these issues contributing to existing discussions on the securitization-humanitarianism-solidarity nexus within 'transit migration 
regimes'. The above-mentioned intertwined practices are deployed as the conceptual analytical tool in the next section in order to understand the responses of different actors to the arrival and transit of refugees within the Croatian part of the Balkan corridor.

\section{THE OCCURRENCE OF THE BALKAN CORRIDOR AND THE CROATIAN RESPONSE}

The preceding historical, socio-political, and institutional context had influenced the ways in which Croatia has dealt with refugees passing through the Balkan corridor. Being traditional emigration country over the centuries, Croatia was affected by the severe war atrocities during the 1990s, experiencing a vast number of displaced persons on its territory. The return or reintegration of displaced persons had been a challenging societal, political and humanitarian endeavour until recently. In harmonizing its legal and institutional framework with the EU acquis, Croatia was the most recent country to enter the EU, yet not a member of the Schengen area to date. Over the last two decades, but prior to the opening of the corridor, the whole Balkan region was known as a transit route for people attempting to reach Western Europe, coming mostly from war-torn and economically deprived countries. The vast majority of people did not choose Croatia as their preferred final destination, nor even as a preferred transit country. Instead, they "end up in Croatia due to circumstances beyond their control and become reluctant asylum-seekers who feel trapped in the country and aspire to leave" (Valenta et al, 2015:95). In that sense, on the periphery of the EU asylum system, they were perceived as "stuck in transit" (Brekke and Brochmann, 2015), becoming "stranded migrants" (Collyer, 2010), or "reluctant asylum seekers" (Valenta et al, 2015). ${ }^{7}$ The annual number of asylum seekers in Croatia had varied, with a slight increase just before joining the EU (exceeding a thousand). However, Croatia's reception capacities have remained the same, consisting of around seven hundred places.

This capacity was certainly not enough when in mid-September 2015, the mass-arrival of thousands of people on the Croatian borders meant the attenuation of the Balkan route, in which refugees tried to circumvent less permeable Hungarian borders from the Serbian side. Out of more than 660,000 refugees and other forcibly displaced persons who passed through the Croatian part of the corridor (with around 5000 daily arrivals), over the following six months only a few hundred people sought protection (ECRE and AIDA, 2016, p.9). Apart from the refugees' agency - that is their motivations and intentions to reach Western Europe - this fact could be partly explained by the shortcomings and systematic deficiencies of the Croatian asylum system, such as a restrictive recognition policy, inadequate living conditions in the accommodation provided, and inadequate opportunities for integration (Baričević, 2013; Coleridge, 2013; Porobić and Župarić-Iljić, 2017). Similar shortcoming conditions also apply to other countries along the Balkan route in which an insignificant number of people had been granted protection over the last decade, and during the existence of the corridor (Lukić, 2016; Kogovšek Šalamon, 2016).

Some reports and studies explain how the EU and countries located on the south-east European periphery actually responded to refugee movements along the Balkan corridor (AI, 2015; HRW, 2015; ACAPS, 2016; MSF, 2016). Croatia's handling of this highly politicized phenomenon began with an offer of immediate help to people arriving at the borders in thousands. The first week brought tensions, diplomatic disputes and accusations flying between the Serbian and Slovenian governments over accepting refugees, and over efficient management for their transportation and transit further West (Šelo Šabić and Borić, 2016, p.12). A week later relations were normalized. On 17 September 2015, the Government established a crisis headquarters for the coordinated action of responsible stakeholders, chaired 
by the Minister of the Interior, "with the aim of humanitarian reception and care of migrants" (Govt, 2015a).

A month later (on 16 October 2015) when Hungary completely closed its border with Croatia, refugees continued to be escorted under tight police control from the Serbian borders to transit reception camps, and later to the Slovenian border. During this period, the former Croatian Government repeatedly stressed their 'humane and humanitarian approach' to 'migrants in transit' (Šelo Šabić, 2017). Furthermore, the relocation and resettlement quotas were accepted by the Government, notwithstanding fierce critiques by the national rightist parliamentary opposition, despite of anti-refugee sentiments and restrictive solutions in neighbouring Hungary and Slovenia.

In the first few days of refugees' arrivals basic assistance was provided by the CRC and by international and national activists in the villages close to border with Serbia. With their expertize, organizational networks and volunteers, pro-refugee organizations and humanitarian actors filled the gap and provided care complementing inadequate and unprepared state response. In the first week, various activists as well as citizens of local border-area communities stepped in, helping refugees by providing them food and water. A little while later, Government opened a temporary reception centre in Opatovac, which was set to accommodate up to 5000 people waiting for few hours before they proceeded to further swift transit. After a month and a half, at the beginning of November, the Opatovac camp closed with the opening of the new Winter Reception Transit Centre in Slavonski Brod. People were taken to this new transit centre from the Serbian border by train, under the police control and escort. The centre's main role was to register those who arrived there, and offer facilities for a short rest (between approximately two and 24 hours). They were given food, clothes and medicine there, before being placed on the next train and escorted to the next stop on the corridor - Slovenia.

In the first period, most humanitarian organisations and non-governmental actors worked together with the authorities without any larger frictions. The assistance offered was more organized and coherent in the new centre, in both a technical and administrative sense, while the accommodation conditions were far better. However, after the establishment of an 'effective' humanitarian system within the reception transit camp(s), securitization practices first came to be criticized by Croatian non-state actors in mid-November 2015. The ethnic and racial profiling of refugees began when the Slovenian government exercised the interception and separation of 'genuine' refugees from war-torn areas (the so-called 'SIA nationals' of Syria, Iraq and Afghanistan), requesting the return and readmission of non-SIA nationals back to Croatia. ${ }^{8}$ During the winter of 2015/2016 non-SIA nationals were repeatedly returned from the Slovenian border to the camp in Slavonski Brod, which continued to serve its registration and short-term stay purposes, whilst increasingly taking on a detainment function.

Securitization and humanitarian practices were implemented there under the same roof, a fact which started to produce ambivalences, tensions and discomfort among some humanitarian organisations. After the complete closing of the Balkan corridor on 9 March 2016, around three hundred persons were returned from Slovenia and Austria to Croatia. They were taken to the camp and detained there for weeks, trapped in-between the aborted continuation of their journeys towards the West, possible separation from family members and/or friends, and the gloomy prospect that they could only move out of the closed camp if they had decided to seek protection in Croatia. The above-mentioned securitization and humanitarian policies revealed both - the complementary and conflicting dimensions of 'crisis management'.

\section{Struggling with arrivals, managing transit: the role of different actors}


Some reports have concluded that during the Balkan corridor, different state (governmental) agencies, together with international agencies, and international and local civil society organizations, enabled appropriate and timely responses to 'humanitarian needs' for refugees transiting through Croatia (Larsen et al., 2016; Šelo Šabić, 2017). These groups of actors - together with the EU as an overarching actor - had had at that time a seemingly identical goal, namely enabling the relatively swift and controlled transcontinental mass movement of the displaced population to states willing to accept them. Yet this goal had not always been coordinated in a safe and satisfactory manner, but instead filled with tensions, ambiguities and limitations. During our visits in the field, we witnessed how the initial response of the Croatian state to large numbers of people arriving was little organized, reactive and $a d$ hoc, with assistance and services provided in an unsystematic manner. ${ }^{9}$ In a situation of massarrivals, local and international organizations and grassroots initiatives, activists and volunteers, coordinated their activities, among each other and with authorities. Authorities and activists shared and exchanged experiences and know-how on the ways how to handle the potential 'humanitarian crisis' at borders, and tried to do the least harm possible for transiting population.

Later on, when the transit reception camp was established, "the response was highly centralized, but it was also multi-sectorial and comprehensive due to the multitude of stakeholders" (Larsen et al., 2016, p.13). The camp was run by the Ministry of the Interior and managed by the National Protection and Rescue Directorate, a state body responsible for dealing with 'disaster management activities', such as floods that hit the Balkans in 2014. Twenty-five local, regional and international NGOs, of various sizes, all provided assistance and aid, coordinated by the CRC, while refugees were staying in transit reception camp(s) for less than 24 hours. Well-known refugee-rights actors, such as CPS and JRS, were involved in the daily activities of the camps, together with newly-established local and regional NGOs and grassroots initiatives, learning all from each other. Some of the humanitarian organizations that worked in the Slavonski Brod camp were local branches of international faith-based groups and charity organizations. The regular inter-agency coordination meetings of international organizations (UNHCR, UNICEF, IOM, and WHO), as well as daily NGO coordination meetings were convened by the CRC. ${ }^{10} \mathrm{New}$ humanitarian actors re-oriented their usual activities in order to provide care and fill the gap created by ambivalent state responses, due to lack of more sensible and permanent protection regimes within the camp.

The initial humane and humanitarian stance of the state accompanied with the spatial isolation, control and detention of refugees was just a part of "a series of contradictions and paradoxes in the Croatian state response to the arrival of a large number of refugees", where the state borders were first and foremost places for 'dehumanizing people', who would then receive humanitarian aid and assistance within transit reception centres, as emphasized by Čapo (2015, p.403). However, this assistance was above all hasty, transient and ephemeral. After the second day in which 11,000 people arrived at the borders the Prime Minister uttered: "You are welcome in Croatia and you can pass through Croatia. But, go on. Not because we don't like you but because this is not your final destination... The European Union must know that Croatia will not become a hotspot for migrants [italics added]" (The Guardian, 2015). This revealed the state's prevailing discourse of advocating a human(itarian) approach, but one which aimed only at permitting a fast transit rather than a permanent stay in Croatia and protection to any larger numbers of asylum seekers. However, it seemed that most actors involved, that is, the local governments along the corridor, the (inter)national non-state organizations, EU officials and refugees/migrants themselves followed this very same logic. It entailed that refugees and other migrants should succeed in their struggle to reach Western Europe from Turkey, trespassing across the Balkan corridor. 
Non-state actors in our research expressed positive views as regards initial governmental attitudes and stances on taking an overtly humanitarian and less-oppressive approach towards managing the mass-arrival and transit of refugees, unlike the military solutions employed by Hungary and Slovenia. Through their daily interaction with refugees passing through the camps, our respondents were quite aware of the fact that almost none of them wanted to stay and apply for protection; rather, they wished to pass and reach Western European countries (most notably Germany). One respondent questioned this presumption relating that to the "[w]ell-known fact of Croatian low asylum-recognition rates and underdeveloped system of integration" (interview CPS). ${ }^{11}$ Other respondents criticized fragmentary EU politics which were unable to sanction unfairness and imbalances in responsibility sharing, while national political institutions had not envisaged this situation nor developed a proper response to it. When asked what that 'proper response' might entail, a RWI respondent posited the state should also look for longer-term solutions such as a full range of rights to protection, outside of the transit camp.

Insights from the transit camp, provided by Škokić and Jambrešić Kirin (2016), unveiled thick description of the tent for the distribution of clothes and footwear as a place where policemen, social workers, volunteers and humanitarian activists cooperated, in so doing creating a certain illusion of "abnormal normality". Daily life in the camp followed known principles of humanitarian-securitarian management. Procedures of hierarchized, carefully planned, high-controlled, security and surveillance measures usually intertwined with a variety of "normalizing humanitarian procedures", used by non-state actors within the camps (Škkokić and Jambrešić Kirin, 2017, p.134). ${ }^{12}$ The authorities' aim to maintain the swift transit resulted in accelerated assistance. However, the camp was also a place which bore witness to refugees' immobilization, with denied or restricted movement outside of the camp and limited movement within the different sectors of the camp, not only for refugees but for humanitarian actors as well (Hameršak and Pleše, 2017a; 2017b).

\section{Humanitarian actors: variations in modes of cooperation and resistance}

It would be wrong to conclude that all of the 25 different organizations, activists and volunteers, working actively in the camp(s) had the same opinions about specific securitization regulations in camp-management. They also differed in opinions on levels and modes of cooperation with state actors and with each other. Our respondents agreed that they had an agenda of helping and providing assistance to people, but their backgrounds, profiles, experiences and expertise differed as well as their capacities, roles and objectives. The majority of civil actors' activities in the camps related to various forms of organizing, collecting, transporting, and distributing direct humanitarian assistance in the form of material humanitarian aid (food, beverages, clothes, footwear). Some also participated through offering healthcare services, or through providing basic educational and language workshops, legal advices, and interpreting to different languages in relation to refugees' and migrants' needs. Alternatively, they simply provided a network of volunteers that assisted the CRC and other humanitarian actors in distributing aid. Nevertheless, they exchanged knowledge and experiences on modes of decentralized self-organization in their daily activities. This included institutional learning from international NGOs and agencies, as well.

Additionally, a few organizations were engaged in informing refugees about their prospects for staying and possibly for applying for asylum in Croatia. Such tasks were undertaken by organizations with experience in advocating for refugees' rights (CPS, Croatian legal centre). All these experiences provided good opportunities for direct personal contact with refugees, which many of the volunteers had not experienced before, and which 
deconstructed some of their prejudices and myths surrounding refugees and humanitarian work. One of the respondents also emphasized the dual benefit of 'working for' and 'working with' refugees, bearing in mind the fact that few organizations (including faith-based ones) had employed couple of the refugees whose status had already been recognized years ago, to work as translators in daily activities (interview JRS). Some witnessed sufferings of their compatriots in transit, recalling their own memories of mobility and/or displacement, and showing 'tremendous compassion and understanding' (volunteer JRS).

In addition to these humanitarian activities, some of the organizations in the camp(s) were active in providing relevant information to media and the general public. They disseminated their reports on the situation in camps, as well as on borders and other locations along the corridor. Sharing information and occasionally coordinating cross-border actions with their colleagues in Serbia and Slovenia involved fostering transnational solidarity networks with refugees and with other organizations along the corridor (Bužinkić, 2017). In the national context their advocacy was based on reflecting and criticizing negative practices within the camps with the aim of advancing the position and rights of refugees (especially of detained ones), and campaigning for a 'welcoming culture' (interview CPS, RWI, AYS, JRS). Oftentimes, these kind of information posed counter hegemonic testimonies which opposed 'official discourses' of the state and spectacularisation in the media. Nevertheless, civil actors were not homogenous, but driven by different motivations and stances towards the state and the 'crisis management approach'. They had different internal logics, organizational ethics, professionalism and dedication in providing aid to refugees and empowering them.

Hence, most of our respondents did not critically examine intertwined discourses and practices within the camps. Only a few were critically oriented in reflecting on securitization practices of the state bodies, mostly those directly interfering with the respondents' everyday activities in the camp (interview CPS, RWI, CBA, AYS). This mainly referred to the separation and isolation of some people, or the forbidding of movement between camp sectors, where single men were often separated from families and vulnerable groups. Most of the respondents did not reflect on their own responsibility in providing humanitarian assistance, which led them to follow official rules, instead of maybe challenging them. Hameršak and Pleše (2017a, p.120) conclude that within the camp, the majority of humanitarian actors were mostly guided by a 'professionalism imperative' in their daily activities. We witnessed this had not been necessary in the sense of obeying to all rules, but sometimes also entailed resisting and circumventing them, especially when opposing predominantly securitising forms of humanitarianism.

At the beginning of mass-arrivals, resistance to securitising humanitarianism was present in solidarity activities of civil actors and ordinary citizens while assisting refugees. Such solidarity occurred over a short period of time in the form of helping refugees to get from the capital city of Zagreb to Slovenia, by giving them a lift to a crossing point on the Slovenian border, around thirty kilometres away. More political forms of solidarity entailed protesting with refugees at border points when they were stopped from entering Slovenia (Ključ Brdovečki, Notes from the borders, 10 October 2015). Civil society organizations continued to act solidary by playing a monitoring role, warning the public of different malpractices such as the ethnic profiling of non-SIA refugees, and other 'undesirable' migrants. This included their political and advocacy engagement in questioning of various arbitrary decisions made by the Ministry of the Interior upon detainment, and the questioning of forced returns and/or violations of rights that started to happen along the borders and within the transit camp, with the gradual closure of the corridor (cf. RWI and AYS, 2017).

Thereby, dealing with the massive movement of refugees in an overtly controlled and securitized manner also depended on humanitarian discourses which gave it a sort of raison d'être. The ways in which different actors handled the situation regarding refugees' mobility through the Balkan corridor had encompassed tendencies which were not opposed to one 
another, but rather complementary - humanitarian and security policies. These included a demand made by civil actors to respect universal human rights, yet it also enabled the shifting the responsibility for coherent assistance and long-term protection, transferring people swiftly to the next state along the corridor. This time the ex-territorialisation (externalization) of the humanitarian regime did not go backwards towards the southeast (cf. Squire, 2009; Triandafyllidou and Dimitradi, 2014), but rather towards the northwest, with the final means of 'assisting' refugees being oriented at receiving protection somewhere else, following the well-known "not-in-my-backyard" logic. This might be phrased as "(Refugees) Welcome, but please continue on...", one respondent expressed sarcastically questioning the official state policy (interview RWI). In that sense, the Balkan countries have reconfigured the level of buffering, speeding up and accelerating the transit to more desired destinations in Western Europe. The specificities of this 'transit humanitarian regime' we explain in more detail on the following pages.

\section{SOLIDARITY WITHIN THE FRAMES OF 'OPPORTUNISTIC HUMANITARIANISM' AND 'SECURITIZATION DISCOMFORT'}

Based on our analysis so far we propose the term 'opportunistic humanitarianism', to understand better Croatian role within the Balkan corridor. We understand it as a concept denoting a strategy and a process of coordinated humanitarian assistance by various stakeholders to forced migrants in transit. This assistance does not stem primarily from the fulfilment of international human rights, refugee protection and/or humanitarian standards and principles, but from the mere opportunity for various stakeholders to act in a human(itarian) manner, providing hasty and temporary aid and assistance. This approach was prioritized by authorities as an imminent crisis management measure of relief for a population in need, and related to the temporality of their transit. Another implication emerging from this assumption relates to a rejection of the political responsibility of the state to thoroughly utilize and exercise international protection standards, in order to provide sustainable alternatives for people to stay and seek protection in Croatia. ${ }^{13}$ By depoliticizing its own responsibility, the state actively depoliticized and securitized refugees only as 'humanitarian subjects' and 'desubjectivized bodies' of bio-politics, who needed to be admitted, eventually registered and later transferred further along the corridor.

Opportunistic humanitarianism does not unfold in a socio-political vacuum, but instead is heavily dependent on various political, soci(et)al, economic, cultural and other factors. Thus, it laid down its rationales, especially in the first few weeks of the refugees' transit through the corridor, in a proclaimed opposition of governmental actors against at least three inter/transnational referral points. The first point of reference was refugees themselves. It was maintained that Croatia was not their preferred destination and that refugees considered the country to be a transit country they had to pass through, in order to reach their intended destinations in Western Europe. The second reference was to the restrictive securitization politics of neighbouring countries which lacked solidarity towards refugees and the countries that received large numbers of refugees. The third reference point was to the politics of solidarity of receiving countries further up in the migration chain (primarily based on their willingness to accept migrants in transit). Moreover, that rationale was dependent on the political context in relation to intra-national (internal) referral points, which at that time entailed parliamentary opposition to 'national democratic' (right-wing) and anti-immigrant sentiment in which state, territorial and border security was a dominant discourse.

In both cases, the former Government tried to justify its strategy by gaining credibility for either being able to follow the EU's 'exceptional policies' for mass arrivals of refugees, for 
following rules and advices to sustain and preserve 'order' by controlling the so-called crisis, at the very edge of the Schengen Area (cf. Govt, 2015b). An ability to manage an emergent mass-arrivals and the swift transit of people in 'human(itarian) way' presumably earned the Croatian Government some political points in front of EU technocratic elites. However, it seems that at that point, the motivations of all actors involved: the state, 'Brussels', the majority of humanitarian organizations, and almost all refugees, were congruent, all being focused on permitting transit of migrants through the corridor to the desired destination. ${ }^{14}$

We saw that, according to several studies, humanitarianism is an overarching strategy used to objectify people as depoliticized and silenced humanitarian clients and victims (Malkki, 1996; Harrell-Bond, 2002; Nyers, 2006). Opportunistic humanitarianism in this case also entails these elements, but it prevails in the context of the massive and transient mobility of a displaced population, in a situation where every or the majority of actors 'governed the unease' in a seemingly humanitarian manner, while transferring responsibility to the next state further up in the migration corridor. Therefore, this strategy heavily depended on a national statecentric position of control and securitization of mass-mobility, which was complemented by urgent and hasty humanitarian assistance at borders and within transit reception camps. The state and civil actors implemented measures of emergency relief while at the same time intentionally dispossessing themselves of responsibility towards the final consequences of their own acts. The legal and political legitimacy of their 'humanitarian' practices stops where responsibility for the next opportunistic humanitarianism regime starts - in our case on the very border with Slovenia. In fact, the majority of national and international humanitarian subjects along the corridor also consented to and followed this game. ${ }^{15}$ Although, was/is there room for an alternative, for solidarity?

It is maintained that the temporality of assistance-provision is the most important aspect of the above-mentioned opportunistic humanitarianism strategy. Even though the movement of refugees through the Croatian part of the corridor lasted for a full six months, its transient and above all controlled character resulted in the general compliance and cooperation of stakeholders. Apart from minor everyday arguments and disagreements over how to operate humanitarian services within the camp, the whole system functioned quite well, as the majority of our respondents agreed and reports confirmed (interview CRC, JRS, CBA, ADRA, CARIT; cf. Larsen et al. 2016; Šelo Šabić, 2017). With increasing concerns that Croatia might become a 'hot-spot' due to the closing of borders further up in the corridor, the opportunistic humanitarianism of authorities shifted to its flipside, a predominantly securitization strategy, leading to moral and organizational discomfort on the part of some non-state organizations. Increased control and restrictions led to disagreements between state actors (who prioritized state security and the security of people in transit) with some non-state actors focusing first and foremost on refugees' benefits, rights and needs. This led to distrust, resistance and finally the disobedience of some non-state actors (but not all). This was especially seen among grassroots citizens' initiatives (AYS and RWI), and some faith-based ones (JRS and CBA), who advocated the human rights of 'forcible immobilized (detained) persons' over the last days of the transit reception camp, and general solidarity with refugees.

Under the circumstances of refugees' detainment 'securitization discomfort' was revealed as disillusionment among civil society actors who realized how the state would eventually try to reassert its preoccupation with security. This discomfort was more or less concealed during the first few months of mutual humanitarian activities and cooperation between stakeholders within the camps. Refugee rights organizations realized that the humanitarian approach of the state was never meant to be a real long-lasting option and permanent strategy, and that prioritizing security would always be dominant. It was simply hindered by an opportunistic humanitarianism approach of the state which actually strived to 'preserve' territory, borders, and imagined nationhood from the influence of transiting 
refugees, who just 'needed' to trespass, while the state 'had to help' them with that. Notwithstanding, overpassing the simplistic view we contend that the authorities had in mind the overall well-being and safeness of people in transit, by sending them further up the corridor. The state worked with and relied on help of humanitarian actors but the inequalities in power relations were challenged and contested only by the latter.

With the closure of the corridor, it became apparent that the state and civic interests, even if they were somewhat converged at the beginning, increasingly diverged over time. Some non-state actors could not continue with a 'business as usual' principle, because that meant accepting evident derogation and the negation of refugees' right to mobility, or to protection and permanent staying in Croatia. It seemed that in our case the ideology of humanitarianism once again facilitated "the erosion of the fundamental principles of refugee protection" (Chimni, 2004, p.3). This led to diminishing cooperation and the fragmenting of the humanitarian civil society sector which was not homogenous in any case. Organizations started to question the real motives and 'authenticity' of other partners, which, presumably, deployed either more people oriented (value-based) or project oriented (instrumental) activities. As one of our respondents stated: "We experienced misunderstandings and conflicts with the CRC, because they called us 'weekend-volunteers' while we had at the same time criticized the inertia and non-responsiveness of 'big' organizations ... even though we certainly thought that our presence on borders and in camps was making a difference, we asked ourselves whether or not we actually help to sustain the apparatus which dehumanizes people?" (interview AYS).

Similarly, MSF report (2016, p.4) challenged the idea that EU agencies and a UNsponsored aid system were able to respond properly to the needs of migrants in transit. It posited that civil society and volunteer groups are those which provide people with essential services on their journeys, because "[a]t the core of these non-state activities has been an overwhelming upsurge in solidarity from citizens volunteering their time, donations and money to assist the tens of thousands in need." (ibid). However, a valid question arises: did all the nonstate actors share the same view on responsibilities to protect and to assist refugees within the transit camp(s), and did they share their views on mutual solidarity at all? Undoubtedly, there were many practices of direct face-to-face solidarity with refugees in the everyday interactions of volunteers, activists and policemen we witnessed in the field, as also described by ethnographic studies (Hameršak and Pleše, 2017a; Škokić and Jambrešić Kirin, 2016). ${ }^{16}$ The same applies for ordinary Croatian citizens, including those formerly displaced themselves, who helped refugees arriving at borders.

Solidarity discourses on a 'welcoming culture' counteracted the ambivalent logic of the state and some anti-refugee voices and sentiments from the public. In a situation in which discourses of crisis (that served to 'other' migrants) obstructed the formation and maintenance of solidarity between citizens and non-citizens, these kinds of persistent solidarity campaigns represented a form of civic resistance to dominant discourses. On the other hand, solidarity with refugees continued to develop among those refugee rights organizations who had previously been involved in working for and with refugees and other migrants before the corridor started, together with engagement of new actors, such as the RWI and AYS initiatives. Some of the citizens with migrant background, and some of recognized refugees joined in these initiatives, as volunteers, thus, fostering the sort of 'migrant humanitarianism' (cf. Pries, in this volume).

Longstanding support and solidarity has evolved from assuming purely humanitarian approaches to those expressing an explicit political framing of solidarity. Although some activists in Croatia were also targeted for their political expressions and opposition to dominant securitization discourses. ${ }^{17}$ Our respondents also perceived a potential for further networking and cooperation in the future, one that might transcend national borders, establishing forms of long-lasting transnational solidarity networks. This was most evident among respondents who 
already had established regional networks and connections with other colleagues from the Balkan region. Presumably, this indicates that 'refugee solidarians' might work on developing more politicised international forms of solidarity and care (cf. Cantat and Feischmidt, in this volume).

\section{CONCLUSION}

The recent events surrounding refugee mobility through the Balkan corridor will be remembered in terms of several unexpected changes made regarding the positioning of countries at the south-eastern frontier of the EU. They formally defined themselves as transit countries, opened their borders and allowed - or even facilitated - their further journey to the next country in the migration chain. These countries combined security oriented measures (interception, deterrence, deportation, readmission, and pushbacks) with direct and indirect humanitarian assistance to refugees and migrants transiting further to 'the core' of the EU. In fact, due to a lack of proper reception capacities, the express transportation of refugees further north and west was seen by these countries as the best way of dealing with the emerging humanitarian issues on less permeable borders and at closed camps.

In this chapter, we have maintained that the dominant Croatian approach to refugees' and migrants' mobility in the corridor was characterized by a combination of state-driven 'crisis management' oriented measures, including the organized but excessively controlled and securitized transit of people. Those measures were exercised together with different practices of immediate care and assistance by state actors, civil society, religious and humanitarian organizations, new civil grassroots initiatives and by other stakeholders. However, in the later stage of the corridor's existence, and with the reinstatement of the Dublin regulation, more and more securitization measures were put in place again, which created tensions and ambiguities between the authorities and parts of civil society.

We posit that 'opportunistic humanitarianism' aimed to facilitate the swift transit of people to the next countries onward. At that time, stakeholders acted and presented the situation as if they were handling it in a humanitarian and overtly supportive manner. That approach of 'transit humanitarian regime' was openly embraced and proclaimed by almost all national actors, the public, and the EU technocrats. But later on, with contextual changes (after the Paris and Cologne events), and with structural changes (new Government following national elections, gradual closing of the corridor,), the positions of Croatian authorities and humanitarian organizations started to diverge more significantly. For national authorities the primary concerns were that border closure might result in Croatia becoming a 'hotspot' for stranded migrants in transit. This triggered a radicalization and securitization of state discourses, rhetoric and politics, as in the rest of the EU.

Within the camps, cooperative solidarity in crisis management activities might have led to a static perspective on what could be considered desirable as a mode of operating for nonstate actors, leaving aside the needs, rights and agency of refugees. Thus, as new civil initiatives became to take roles of new political subjects, they circumvented risk of falling into the trap of narrowing themselves to (only) humanitarian subjectivities. Later on, enduring occasional frictions and contraposed stances to state-centric hegemonic perspectives, solidarity among activists was built around the similar dedication of a few of the organizations and initiatives in their struggle to partake in a 'watch-dog role'. This mostly meant informing the public about malpractices conducted by the state in the period followed by the closure of the corridor (RWI, AYS and JRS), which deepened further 'securitization discomfort'.

This referred to a condition in which non-state humanitarian actors find themselves in an ambiguous dialectics of attempting to balance between their mission/orientation to provide 
care to people and their innate obligation to cooperate with state who started to exaggerate power by detaining and push-backing 'migrants'. In the meantime, the state has undergone a process of hardening the forced migrants' chances of entering the territory and seeking protection. A large burden and challenge surrounds the obtaining of a sufficient quality of protection relating to needed, but poorly implemented integration measures. Consequently, all these contradictions force pro-refugee rights actors to engage in a somewhat difficult balancing act, caught between cooperation and partnership, and/or opposition and conflict with state bodies, particularly as regards refugee protection standards.

Nowadays, new civic initiatives are institutionalizing their organisational forms and activities, and some have reoriented their usual objectives towards the refugee population. At the same time, a struggle to advocate and lobby for a more sensible and inclusive system of refugee protection continues, as well as practices of direct assistance, facilitated integration and socio-economic empowering of persons with migrant background (cf. Taste of Home, 2017). As some of the respondents emphasized their goal is to make interactions with people of concern, seeing them as equal partners, proponents and agents of their own empowerment going beyond humanitarianism dichotomy of 'care-providers' vs 'care-receivers'. Thus, solidarity between citizens and refugees represents an act of civil resistance to this dominating state approach, the former representing a potential which might help build foundations for a regional and transnational pro-refugee solidarity movement.

\section{References}

ACAPS (2016) The Balkan Migrant Crisis: AN INTRODUCTION, January 2016, www.alnap.org/pool/files/the-balkan-migrant-crisis.pdf

Agier, M. (2011) Managing the Undesirables: Refugee Camps and Humanitarian Government (Cambridge: Polity Press).

Alexandridis, A. and Müge, D. (2017) Routes Change, Migration Persists: The Effects of EU Policy on Migratory Routes (Istanbul: Alsharq Forum Paper Series), http://sharqforum.org/2017/03/28/routes-change-migration-persists-the-effects-of-eu-policyon-migratory-routes/.

AI - Amnesty International (2015) Fear and Fences Europe's Approach to Keeping Refugees at Bay, London, https://www.amnesty.org/en/documents/eur03/2544/2015/en/.

Aydin, Y. (2016) The Germany-Turkey Migration Corridor: Refitting Policies for a Transnational Age (Washington DC: Migration Policy Institute). http://www.migrationpolicy.org/research/germany-turkey-migration-corridor-refittingpolicies-transnational-age.

AYS - Are You Syrious? (2017) https://www.facebook.com/areyousyrious, date accessed 11 December 2017

Banich, S., Lukas G. and Adrienne H. (2016) Report on Systemic Police Violence and Push-Backs against Non-SIA People Conducted by Croatian Authorities, Moving Europe Project 28, 2016, http://moving-europe.org/wp-content/uploads/2016/01/28.01.2016_ReportPolice-Violence-and-Push-Backs.pdf.

Barberić, J. (2015) Asylum in the Republic of Croatia one year after accession to the European Union. New Issues in Refugee Research, Research paper no. 273. UNHCR, Policy Development and Evaluation Service, http://www.unhcr.org/research/working 154dca6ee9/asylum-republic-croatia-year-accession-european-union-jasna-barberi.html. 
Baričević, V. (2013) Europeanization of Asylum System and Refugee Protection: Croatian Asylum and Migration Policies (University of Ljubljana: Faculty of Social Sciences - PhD Thesis).

Barnett, M. and Weiss, T.G. (2008), 'Humanitarianism. A Brief History of the Present', in M. Barnett and T.G. Weiss (eds.) Humanitarianism in question: politics, power, ethics (Ithaca: Cornell University Press).

Bello, V. (2017) Europe and the Mediterranean Crises: Trapped Between Prejudice and Solidarity, Policy Report No. 04/01 (Barcelona: United Nations University Institute on Globalization, Culture and Mobility).

Belloni, R. (2007) ‘The trouble with humanitarianism', Review of International Studies (33): 451-474.

Beznec, B.; Speer, M. and Stojić Mitrović, M. (2016) Governing the Balkan Route. Macedonia, Serbia and European Border Regime (Beograd: Rosa Luxemburg Stiftung Southeast Europe), http://bordermonitoring.eu/wp-content/uploads/2017/01/5-Governing-theBalkan-Route-web.pdf

Brekke, J.-P. and Brochmann, G. (2015) 'Stuck in Transit: Secondary Migration of Asylum Seekers in Europe, National Differences, and the Dublin Regulation', Journal of Refugee Studies, 28(2): 145-162.

Bryman, A. (2012) Social Research Methods, Oxford University Press.

Buzan, B.; Wæver, O. and de Wilde, J. (1998) Security: A new framework for analysis (BoulderCO: Lynne Rienner).

Bužinkić, E. (2017) 'Dobrodošli vs. dobroprošli: krizna mobilizacija i solidarizacija s izbjeglicama u Hrvatskoj kao tranzitnoj zemlji', in E. Bužinkić and M. Hameršak (eds) Kamp, koridor, granica: studije izbjeglištva u suvremenom hrvatskom kontekstu (Zagreb: Institut za etnologiju i folkloristiku).

Cantat, C. (2016) 'Rethinking Mobilities: Solidarity and Migrant Struggles Beyond Narratives of Crisis', Intersections. East European Journal of Society and Politics, 2(4): 1132.

Coleridge, B. (2013) From Back Door to Front Door: Forced Migration Routes Through Macedonia to Croatia (Brussels: Jesuit Refugee Service Europe).

Collyer, M. (2010) 'Stranded Migrants and the Fragmented Journey', Journal of Refugee Studies, 23(3): 273-293.

Čapo, J. (2015) 'The Security-scape and the (In)Visibility of Refugees: Managing Refugee Flow through Croatia', Migracijske i etničke teme, 31(3): 387-406.

De Genova, N. (2013) 'Spectacles of Migrant 'Illegality': The Scene of Exclusion, the Obscene of Inclusion', Ethnic and Racial Studies, 36(7): 1180-1198.

ECRE and AIDA - The European Council on Refugees and Exiles and the Asylum Information Database (2016). Balkan route reversed: The return of asylum seekers to Croatia under the Dublin system. http://www.asylumineurope.org/sites/default/files/resources/balkan_route_reversed.pdf

Fassin, D. (2012) Humanitarian Reason. A Moral History of the Present (Berkeley: University of California Press).

Funk, N. (2016) 'A spectre in Germany: refugees, a 'welcome culture' and an 'integration politics', Journal of Global Ethics, 12(3): 289-299.

Goldner Lang, I. (2013) 'Is There Solidarity on Asylum and Migration in the EU?', Croatian yearbook of European law \& policy, 9(9): 1-14.

Govt - Government of the Republic of Croatia (2015a) Odluka o osnivanju stožera za koordinaciju aktivnosti povodom dolaska migranata u Republiku Hrvatsku, https://vlada.gov.hr/UserDocsImages/Sjednice/2015/253\%20sjednica\%20Vlade/253\%20\%2013.pdf. 
Govt (2015b), 'PM Milanovic says gov't has refugee crisis under control', 19.10.2015, https://vlada.gov.hr/news/pm-milanovic-says-gov-t-has-refugee-crisis-under-control/17952.

Hameršak, M. and Pleše, I. (2017a) 'Winter Reception and Transit Center in the Republic of Croatia: An Ethnographic View of the Slavonski Brod Refugee Camp', Narodna umjetnost, 54(1): 101-127.

Hameršak, M. and Pleše, I. (2017b) 'Zarobljeni u kretanju: o hrvatskoj dionici balkanskog koridora' in E. Bužinkić and M. Hameršak (eds) Kamp, koridor, granica: studije izbjeglištva u suvremenom hrvatskom kontekstu (Zagreb: Institut za etnologiju i folkloristiku).

Harrell-Bond, B. (1999) 'The experience of refugees as recipients of aid', in A. Ager (ed) Refugees: Perspectives on the Experience of Forced Migration (London: Cassell).

Harrell-Bond, B. (2002) 'Can humanitarian work with refugees be humane?', Human Rights Quarterly, 24(1): 51-85.

HRW - Human Rights Watch (2015). Europe's Refugee Crisis: An Agenda for Action. https://www.hrw.org/report/2015/11/16/europes-refugee-crisis/agenda-action.

Huysmans, J. (2006) The Politics of Insecurity. Fear, Migration and Asylum in EU (London, New York: Routledge).

Kogovšek Šalamon, N. (2016). 'Asylum Systems in the Western Balkan Countries: Current Issues', International Migration, 54(6): 151-163.

Larsen, M., Demir, E. and Horvat, M. (2016). Humanitarian responses by local actors: Lessons learned from managing the transit of migrants and refugees through Croatia. IIED Working Paper (London: International Institute for Environment and Development), http://pubs.iied.org/pdfs/10795IIED.pdf.

Lukić, V. (2016) 'Understanding Transit Asylum Migration: Evidence from Serbia', International Migration, 54(4): 31-43.

Malkki, L. (1995) 'Refugees and Exile. From 'Refugee Studies' to the National Order of Things', Annual Review of Anthropology (24): 495-523.

Malkki, L. (1996) 'Speechless Emissaries: Refugees, Humanitarianism, and Dehistoricization', Cultural Anthropology, 11(3): 377-404.

MoI - Ministry of Interior of the Republic of Croatia (2015) Archive 2015: reception and accommodation of migrants, http://stari.mup.hr/main.aspx?id=225851, date accessed 11 December 2017

MSF - Medecins Sans Frontieres (2016) Obstacle Course to Europe: A policy-made humanitarian crisis at EU borders, Brussels. http://www.doctorswithoutborders.org/article/obstacle-course-europe-policy-madehumanitarian-crisis-eu-borders.

Nyers, P. (2006) Rethinking Refugees: Beyond States of Emergency (New York: Routledge).

OXFAM, BCHR and MYLA (2017) A dangerous 'game': the pushback of migrants, including refugees, at Europe's borders, Oxfam, Belgrade Centre for Human Rights and Macedonian Young Lawyers Association, https://www.oxfam.org/sites/www.oxfam.org /files/file_attachments/bp-dangerous-game-pushback-migrants-refugees-060417-en_0.pdf

Petrović, D. (2016) Izbjeglištvo u suvremenom svijetu. Od političkoteorijskih utemeljenja do biopolitičkih ishoda (Zagreb: Naklada Ljevak).

Porobić, S. and Župarić-Iljić, D. (2017). 'Access to Asylum and Reception Conditions in Western Balkans: Focus on Bosnia and Herzegovina and Croatia', in M. O'Sullivan and D. Stevens (eds.), States, the Law and Access to Refugee Protection: Fortresses and Fairness (Oxford: Hart Publishing).

Rajaram, P.K. (2002) 'Humanitarianism and Representations of the Refugee', Journal of Refugee Studies, 15(3): 247-264. 
RWI - $\quad$ Refugees Welcome Initiative

http://welcome.cms.hr/index.php/en/about/, date accessed 11 December 2017

RWI and AYS? (2017) Report on illegal and forced push backs of refugees from the

Republic of Croatia, Zagreb, January 24th 2017, http://welcome.cms.hr/wpcontent/uploads/2017/01/REPORT-ON-ILLEGAL-AND-FORCED-PUSH-BACKS-OF-

REFUGEES-FROM-THE-REPUBLIC-OF-CROATIA.pdf

Squire, V. (2009) The Exclusionary Politics of Asylum (London and New York: Palgrave Macmillan).

Šelo Šabić, S. and Borić, S. (2016) At the Gate of Europe: A report on Refugees on the Western Balkan Route, Zagreb: Friedrich Ebert Stiftung, April 2016, http://www.fescroatia.org/fileadmin/user_upload/At_the_Gate_of_Europe_WEB.pdf.

Šelo Šabić, S. (2017) 'Humanitarianism and its limits: The refugee crisis response in Croatia', in M. Barlai, B. Fähnrich, C. Griessler, and M. Rhomberg (eds.) The Migrant Crisis: European Perspectives and National Discourses (LIT Verlag Münster).

Škokić, T. and Jambrešić Kirin, R. (2017) 'The Shopping Center of Abnormal Normality: Ethnography of the Distribution Tent in the Refugee Camp in Slavonski Brod', Narodna umjetnost. 54(1): 129-146.

Taste of Home (2017) http://www.okus-doma.hr/en date accessed 11 December 2017

The Guardian (2015) 'Croatia 'will not become a migrant hotspot' says prime minister', Matthew Weaver, 18 Sep 2015, www.theguardian.com/world/2015/sep/18/croatia-refugeeszoran-milanovic-migrant-hotspot

Ticktin, M. (2014) 'Transnational Humanitarianism?', Annual Review of Anthropology, (43): 273-289

Triandafyllidou, A. and Dimitriadi, A. (2014) 'Deterrence and Protection in the EU's Migration Policy’, The International Spectator, 49(4): 146-162.

Valenta, M.; Zuparic-Iljic, D. and Vidović, T. (2015) 'The Reluctant Asylum-Seekers: Migrants at the Southeastern Frontiers of the European Migration System', Refugee Survey Quarterly, 34(3): 95-113.

Watson, S. (2011) 'The 'human' as referent object? Humanitarianism as securitization', Security Dialogue, 42(1): 3-20.

Drago Župarić-Iljić, PhD, is a sociologist currently working as a Research Associate at the Institute for Migration and Ethnic Studies in Zagreb, and teaching at the Faculty of Social Sciences and Humanities, at the University of Zagreb, Croatia. His research, within the interdisciplinary fields of forced migration, asylum, ethnicity and environmental studies, focuses on various structural causes and drivers of migration, mobility and post-migration phenomena. He has published articles on topics of migration, asylum, refugee, national minorities, integration and environmental issues, with a special concern on Central and SouthEast Europe. He edited a book about development of asylum protection systems in Croatia and the Balkan countries.

Marko Valenta is a sociologist and full-time professor at the Norwegian University of Science and Technology (NTNU), in Trondheim, Norway. He undertook his graduate work in Sociology at the Norwegian University of Science and Technology where he also received his $\mathrm{PhD}$ in Sociology. His research interests are: ethnic relations, welfare (public) policy, and international migrations and migration/refugee policies in West-Balkan countries, Scandinavian countries and the Middle East. He has published articles in leading journals in 
sociology, social work and migration studies, such as The Journal of Refugee Studies, Symbolic Interaction and The Journal of Ethnic and Migration Studies, and Ethnicities. His most recent book, Ethnic Minorities and Politics in Southeastern Europe (co-edited with Sabrina Ramet) was published by Cambridge University Press in 2016.

\footnotetext{
${ }^{1}$ Here we refer to the population of refugees and other forced migrants not in a legal(istic) sense but rather using a sociological concept of forced migrants, internationally displaced and uprooted persons, who might be(come), or not, international asylum (protection) seekers.

${ }^{2}$ We contend that some aspects of managing these phenomena have been coined as a 'refugee/migrant crisis' by stakeholders in order to utilize crisis and humanitarian management measures towards people coming and passing through the corridor, or getting stuck at borders.

3 We understand the "Balkan route" as the transcontinental land migration path that follows the Eastern Mediterranean route, connecting the Middle East with the territories of Central and West Europe. At the same time, we use the term "Balkan corridor" to refer to intergovernmental, politically institutionalized, controlled and secured, yet often troublesome, legally ambiguous, although formalized, narrow physical passage for the swift transit of more than a million refugees along the Balkan route. It started in late summer 2015, and was almost completely closed by March 2016.

${ }^{4}$ The interviews were conducted with experts working in refugee rights organizations from Croatia: Croatian Red Cross (CRC), Centre for Peace Studies (CPS), Are You Syrious? (AYS), Jesuit Refugee Service (JRS), Refugee Welcome Initiative (RWI), Caritas (CARIT), Majlis of Islamic community in Slavonski Brod (MAJLIS), Meshihat of Islamic community in Zagreb (MESH), Croatian Baptist Aid (CBA), Adventist Development and Relief Agency (ADRA). In the field we partook in volunteering, talking to people, observing and making occasional notes. There were two visits to the reception camp in Opatovac and to the border-points in Bapska and Tovarnik (September and October 2015), and two visits to the reception camp in Slavonski Brod (December 2015, March 2016). A couple of visits to unofficial border crossings spots with Slovenia and different sites in Zagreb were in the autumn of 2015.

${ }^{5}$ Hameršak and Pleše $(2017$ b, p.22-23) contend that one should not overemphasize the humanitarian dimension of the corridor, because it served the specific purpose of constraining, controlling and passivizing the mobility of people, or even forcibly returning them in the opposite direction. They portray the corridor as a form of "mobile detention" consisting of sealed transport and closed camps at occasional stops along the route. We argue that in these circumstances of overtly controlled transient mobility refugees could have expected to encounter a humanitarian stance on the part of the Croatian government, which we elaborate later.

${ }^{6}$ Ticktin (2014, p.281) writes about "a regime of care and also violence" while Watson (2011, p.9) calls this nexus 'humanitarian securitization'. Petrović (2016, p.396-409) describes the transit camp in Croatia as located on an isolated, remote spot outside of town and out of public sight, surrounded by a fence, as a place where the governing policy of 'securitarian humanitarianism' prevailed.

${ }^{7}$ The UNHCR data suggested that more than eighty percent of asylum seekers left the country irregularly before the first instance decision was made (Barberić, 2015, p.2). During the period from 2004 when the first Asylum Law was enacted up until the end of 2017, Croatia has received around 9000 asylum seekers - a considerably lower number than in other European countries, with only 400 of them being granted with protection.

${ }^{8}$ The seclusion and segregation was conducted by border police on the questionable basis of ethnic and racial profiling, with the help of official translators (oftentimes even of migrants' origin) and subject to very arbitrary provisions (Banich et al., 2016; Beznec et al., 2016; OXFAM et al., 2017). These malpractices point that some of translators might have misused their power position (as interlocutors and mediators) in-between policemen and refugees.

${ }^{9}$ For the official Ministry of Interior daily reports on arrivals, reception, accommodation and transit of 'migrants' please see MoI (2015).

${ }^{10}$ The CRC was mandated by the Government in daily running the camp, with several humanitarian agencies as well as informal civic and youth initiatives who participated in the provision of daily services within the camp: Information Legal Centre, Croatian Legal Centre, CPS, Youth Peace Group Danube, AYS, RWI, CARIT, CBA, MESH, MAJLIS, and Volunteer Centres of Slavonski Brod and Osijek. International agencies and international NGOs included Save the Children International, ADRA, Centre for Support to Immigrant Communities, Magna, Samaritan's Purse, JRS, Remar, Intereuropean Human Aid Association, as well as the UN related agencies (UNHCR, UNICEF, IOM, WHO) (Larsen et. al, 2016:14). While some faith-based organizations were more engaged in distributing aid (CBA, ADRA, JRS, Samaritan's Purse), others were also involved in care for the religious needs of the mostly Muslim refugees (MAJLIS, MESH).

${ }^{11}$ The CPS coordinates the "Refugees Welcome initiative (RWI)", gathering sixty civil society organisations, with more than 400 activists and volunteers who provided assistance and support to refugees at borders, and in the camps, also fostering strong advocacy work (cf. RWI, 2017). “Are You Syrious?" (AYS) started in the summer
} 
2015 as a citizen, grass-roots, initiative which provided direct humanitarian aid and assistance mostly out of the structured camp areas, gathering more than a hundred active volunteers from Croatia and abroad. Both initiatives operate mainly through social networks and social media providing practical information to refugees and practitioners. AYS "daily digest" remains one of the most informative and reliable sources of news for refugees, volunteers, journalists, and the general public (cf. AYS, 2017).

12 These procedures of 'normalizing securitization abnormalities' were often associated with administrative norms. However, on some occasions they acted against them, more or less directly and successfully. For example, this was evident in occasions when refugees asked volunteers to buy them products from the shops in the town, since they were not allowed to leave the camp. Some volunteers smuggled-in small products including mobilephone cards, food, or medicine they asked for. Although this was not a clearly regulated (or forbidden) act, it was done in furtive and covert way (Slavonski Brod, Notes from the camp, 27 March 2016).

13 This shows that setting up proper asylum structures is not the main answer to the current situation, which involves people who clearly need international protection, but do not wish to stay in the countries they are transiting through. Kogovšek Šalamon (2016, p.160) argues that "from the constitutional point of view there is also a need to legalize this situation in such a way that basic rights are provided for prima facie refugees, regardless of whether they stay and apply for asylum or not".

${ }^{14}$ Furthermore, it seemed that the media and public were in support of a governmental 'humanitarian approach' when refugees first started to arrive, without any serious protests against this approach. This slightly changed after the Paris and Cologne events, which resulted in deepening practices of public condemnation for the acceptance of refugees, fostering victimization, criminalization and the militarization of refugee issues among policy makers and the European public.

${ }^{15}$ We do not posit that all other Balkan countries' responses can be seen through this lense. It seems that the Macedonian approach was heavily based on securitization and militarization (cf. Beznec et al 2016). It could be argued whether the Serbian response may also be seen as a kind of 'opportunistic humanitarianism' since they decided to allow the spontaneous movement of refugees through Serbia, only later securitizing it, when the corridor was gradually closing. The general impression is that each state in the region took a strategy that it thought would best provide a delicate balance between their national interests and EU demands.

${ }^{16}$ In the transit camps we noticed more of a need-based solidarity among the stakeholders directed not only towards refugees. Collaboration between the state and humanitarian and other agencies was especially pronounced in the sharing of human resources, such as translators for Arabic, Urdu and Farsi, as also confirmed by our respondents (interview CRC, CPS, MAJLIS, JRS). Many of the daily camp activities revealed different practices of solidarity activism that went against the logic of exclusion, and which aimed at establishing solidarity networks (interview JRS).

${ }^{17}$ Proposed, yet not enacted changes in national Croatian asylum and migration law laid down provisions which tend to criminalize and penalize any solidarity practices related to citizens' offering of direct help and support to forced migrants, pushing the debate further into the scope of irregularities and criminal acts. At the same time, the introduction of legal provisions for a possible army presence on the borders in the case of mass-arrivals meant militarization of refugee-related issues. Our respondents concluded this might tend to serve as one of fragmenting tactics which would prevent or demotivate locals for solidarity with refugees and migrants, that few of the organizations will continue to advocate for (interview JRS, CPS, AYS). 